\title{
Impementasi Project Based Learning Dalam Pembelajaran Abad 21 Pada Mata Pelajaran Geografi Kelas XI IPS SMA Nasional 3 Bahasa Putera Harapan Purwokerto
}

\author{
Project Based Learning Implementation in the $21^{\text {st }}$ Century Learning on Geography Subject \\ Class of XI Social Sciences Major at SMA Nasional 3 Bahasa Putera Harapan Purwokerto
}

Ika Pujiastuti

SMA Nasional 3 Bahasa Putera Harapan Purwokerto

\begin{abstract}
ARTICLE INFO
Article history:

DOI:

10.30595/pssh.v1i.66

Submitted:

April 12, 2021

Accepted:

June 10, 2021

Published:

June 14, 2021

ABSTRACT

The development of curriculum in schools is currently required to make changes in implementing teacher-centered learning approaches into student-centered learning approaches. This is adjusted to the demands of learning that will affect the development of children in the future, where children must have thinking and learning skills. These skills include critical thinking skills, problem solving, collaboration, and communication skills. These skills are often said to be skills in the independent learning process that must be possessed by students. Students can have these skills if the teacher is able to develop learning with activities that challenge students to think critically in solving problems. Another aspect that is no less important is the Assessment or Assessment. Assessment can be given among students as feedback, by the teacher with an assessment rubric that has been prepared by the teacher or based on the performance and products they produce. To achieve the aforementioned objectives, a learning approach that is quite challenging for teachers is a project-based learning (PBL) approach.
\end{abstract}

Keywords:

Project Based Learning,

Independent Learning
This work is licensed under a Creative Commons Attribution 4.0 International License.

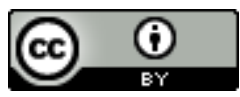

\section{Corresponding Author:}

Ika Pujiastuti

SMA Nasional 3 Bahasa Putera Harapan, Purwokerto

Jalan S.Parman, depan stadion mini, Purwokerto Selatan

Email: ikapujiastuti.puhua@gmail.com

\section{PENDAHULUAN}

Pembelajaran abad 21 adalah pembelajaran yang dirancang untuk generasi abad 21 agar mampu mengikuti arus perkembangan teknologi terbaru. Terutama pada ranah komunikasi yang telah masuk ke sendi kehidupan, maka dari itu siswa diharuskan untuk bisa menguasai empat keterampilan belajar (4C), yakni: creativity and innovation, critical thinking and problem solving, communication dan collaboration. Pembelajaran abad 21 bisa ditandai dengan perubahan paradigma teaching (root learning) menjadi learning (deep learning). Bila ditarik dari manusianya pembelajaran abad 21 bertujuan agar manusia bisa relevan dengan zamannya, terutama manusia Indonesia maka terbentuklah inisiasi dari pembelajaran abad 21. Inilah salah satu instrumen untuk 'membeli' masa depan. Karena pengaruhnya yang signifikan itulah siswa diharap mampu beradaptasi dengan zaman sehingga nantinya mereka bisa berkompetisi dengan baik di masa yang akan datang.

Pembelajaran abad 21 merupakan pembelajaran yang mempersiapkan generasi penerus menjadi generasi yang memiliki kemampuan kecakapan abad 21. Setidaknya ada empat hal yang harus dimiliki oleh generasi abad 21, yaitu: ways of thingking, ways of working, tools for working and dan skills for living in the word. Bagaimana seorang guru 
dapat mendesain pembelajaran yang akan menghantarkan peserta didik memenuhi kebutuhan abad 21. Pembelajaran abad ke-21 yang berpusat pada siswa berbeda dengan pembelajaran tradisional yang berpusat pada guru, dalam arti bahwa keduanya memiliki pendekatan yang berbeda terhadap isi, pembelajaran, lingkungan ruang kelas, penilaian, dan teknologi. Hal ini yang menjadikan hal yang harus dimiliki oleh siswa sebagai peserta didik yang tergabung dalam empat cara yaitu : way of thinking, cara berfikir yaitu beberapa kemampuan berfikir yang harus dikuasai peserta didik untuk menghadapi dunia abad 21. Kemampuan berfikir tersebut diantaranya: kreatif, berfikir kritis, pemecahan masalah, pengambilan keputusan dan pembelajar. Ways of working, kemampuan bagaimana mereka harus bekerja dengan dunia yang global dan dunia digital. Beberapa kemampuan yang harus dikuasai peserta didik adalah communication and collaboration. Generasi abad 21 harus mampu berkomunikasi dengan baik, dengan menggunakan berbagai metode dan strategi komunikasi. Disamping itu mereka juga harus mampu berkolaborasi dan bekerja sama dengan individu maupun komunitas dan jaringan. Jaringan komunikasi dan kerjasama ini memanfaatkan berbagai cara, metode dan strategi berbasis ICT. Bagaimana seseorang harus mampu bekerja secara bersama dengan kemampuan yang berbeda-beda. Tools for working, dimana seseorang harus memiliki dan menguasai alat untuk bekerja. Penguasaan terhadap Information and communications technology (ICT) and information literacy merupakan sebuah keharusan. Tanpa ICT dan sumber informasi yang berbasis segala sumber akan sulit seseorang mengembangkan pekerjaannya. Skills for living in the world, dimana kemampuan untuk menjalani kehidupan di abad 21, yaitu: Citizenship, life and career, and personal and social responsibility. Bagaimana peserta didik harus hidup sebagai warga negara, kehidupan dan karir, dan tanggung jawab pribadi dan sosial. Kemampuan-kemampuan yang harus dimiliki itu yang terintegrasi dalam satu kecakapan yaitu kecakapan abad 21. Secara umum, kecakapan abad 21 meliputi :

A. Kecakapan Pembelajaran dan Inovasi

1) Kreativitas dan Inovasi

2) Pemikiran Kritis dan Pemecahan Masalah

3) Komunikasi dan Kolaborasi

B. Kecakapan Informasi, Media dan Teknologi

1) Literasi Informasi

2) Literasi Media

3) Literasi ICT

C. Kecakapan Kehidupan dan Karier

1) Fleksibilitas dan Kemampuan Beradaptasi

2) Inisiatif dan Kemandirian

3) Kecakapan Lintas Budaya

4) Produktivitas dan Akuntabilitas

5) Kepemimpinan dan Tanggung Jawab

\section{METODE PENELITIAN}

\section{A. Project Based Learning (PBL)}

Project Based Learning (PBL) merupakan satu dari banyak model pembelajaran yang sudah banyak dikembangkan di negara-negara maju dan banyak diimplementasikan di banyak lembaga-lembaga guruan baik lembaga guruan formal maupun non formal. Terjemahan dalam bahasa Indonesia, Project Based Learning bermakna sebagai pembelajaran berbasis proyek. Definisi secara lebih komperehensif tentang Project Based Learning menurut The George Lucas Educational Foundation (2005) adalah sebagai berikut :

a. Project-based learning is curriculum fueled and standards based. Project Based Learning merupakan pendekatan pembelajaran yang menghendaki adanya standar isi dalam kurikulumnya. Melalui Project Based Learning, proses inquiry dimulai dengan memunculkan pertanyaan penuntun (a guiding question) dan membimbing siswa dalam sebuah proyek kolaboratif yang mengintegrasikan berbagai subjek (materi) dalam kurikulum. Pada saat pertanyaan terjawab, secara langsung siswa dapat melihat berbagai elemen mayor sekaligus berbagai prinsip dalam sebuah displin yang sedang dikajinya (The George Lucas Educational Foundation: 2005).

b. Project-based learning asks a question or poses a problem that each student can answer. Project Based Learning adalah model pembelajaran yang menuntut guru dan atau siswa mengembangkan pertanyaan penuntun (a guiding question). Mengingat bahwa masing-masing siswa memiliki gaya belajar yang berbeda, maka Project Based Learning memberikan kesempatan kepada para siswa untuk menggali konten (materi) dengan menggunakan berbagai cara yang bermakna bagi dirinya, dan melakukan eksperimen secara kolaboratif. Hal ini memungkinkan setiap siswa pada akhirnya mampu menjawab pertanyaan penuntun (The George Lucas Educational Foundation : 2005). 
c. Project-based learning asks students to investigate issues and topics addressing realworld problems while integrating subjects across the curriculum. Project Based Leraning merupakan pendekatan pembelajaran yang menuntut siswa membuat "jembatan" yang menghubungkan antar berbagai subjek materi. Melalui jalan ini, siswa dapat melihat pengetahuan secara holistik. Lebih daripada itu, Project Based Learning merupakan investigasi mendalam tentang sebuah topik dunia nyata, hal ini akan berharga bagi atensi dan usaha siswa (The George Lucas Educational Foundation: 2005).

d. Project-based learning is a method that fosters abstract, intellectual tasks to explore complex issues. Project Based Learning merupakan pendekatan pembelajaran yang memperhatikan pemahaman. Siswa melakukan eksplorasi, penilaian, interpretasi dan mensintesis informasi melalui cara yang bermakna. (The George Lucas Educational Foundation: 2005). Berdasarkan definisi-definisi tersebut di atas, dapat disimpulkan bahwa Project Based Learning (PBL) merupakan serangkaian aktivitas pembelajaran siswa yang menuntun siswa untuk melakukan kegiatan pemecahan masalah melalui langkah-langkah pembelajaran yang meliputi pengamatan (observasi), wawancara atau tanya jawab, menggali ilmu secara mandiri, eksperimen, einvestigasi, kerjasama atau kolaborasi dalam satu kelompok diskusi, eksplorasi, penilaian, interpretasi hingga presentasi hasil pembelajaran.

Project Based Learning memiliki karakteristik sebagai berikut:

a) Siswa menjadi pusat atau sebagai obyek yang secara aktif belajar pada proses pembelajaran.

b) Proyek-proyek yang direncanakan terfokus pada tujuan pembelajaran yang sudah digariskan dalam Standar Kompetensi dan Kompetensi Dasar dalam kurikulum

c) Proyek dikembangkan oleh Pertanyaan-pertanyaan sebagai kerangka dari kurikulum (curriculum-framing question)

d) Proyek melibatkan berbagai jenis dan bentuk assessmen yang dilakukan secara kontinyu (on going asessment)

e) Proyek berhubungan langsung dengan dunia kehidupan nyata.

f) Siswa menunjukkan pengetahuannya melalui produk atau kinerjanya.

g) Teknologi mendukung dan meningkatkan proses belajar siswa.

h) Keterampilan berpikir terintegrasi dalam proyek.

i) Strategi pembelajarn bervariasi karena untuk mendukung oleh berbagai tipe belajar yang dimiliki oleh siswa (multiple learning style).

Berdasarkan pendapat-pendapat di atas, dapat dikatakan bahwa pendekatan Project Based Learning dikembangkan berdasarkan faham filsafat konstruktivisme dalam pembelajaran. Project Based Learning merupakan pendekatan pembelajaran yang dapat memberikan kebebasan kepada siswa untuk merencanakan aktivitas belajar, melaksanakan proyek secara kolaboratif dalam memecahkan permasalahannya, dan pada akhirnya menghasilkan produk kerja yang dapat dipresentasikan kepada orang lain yang dapat dijadikan rekomendasi dalam memecahkan permasalahannya. Dalam menerapkan pembelajaran berbasis proyek, siswa bekerja pada masalah atau proyek terbuka. Pembelajaran berpusat pada siswa dengan guru sebagai fasilitator. Siswanya biasanya bekerjasama dalam kelompok untuk jangka waktu yang lama, mencari beragam sumberdaya informasi dan menciptakan produk-produk otentik yang pada akhirnya dijadikan sebagai rekomendasi dalam pemecahan masalah. Perbandingan pembelajaran antara pembelajaran menggunakan pendekatan konvensional dengan pembelajaran menggunakan pendekatan berbasis proyek.

\section{A. Konvensional, meliputi Berpusat pada guru, Dibimbing guru, Mendengarkan, mengingat,}

Mengulangi, Kemandirian, Pengambilan keputusan oleh guru, Pengetahuan atas fakta, istilah dan isi, Instruksi langsung, Pelajaran singkat dan terisolasi dengan jawaban yang telah ditentukan sebelumnya, Berbasis standar, Penilaian Ujian, Aktivitas berbasis sekolah, Kuis dan Ujian.

B. Berbasis Proyek meliputi Berpusat pada siswa, Mandiri, Menemukan, Menerapkan,

Menyajikan, Kolaborasi, Siswa dan guru mengambil, Kecakapan Abad-21, Beragam strategi instruksional, Penyelidikan jangka panjang, Berbasis standar, Penilaian yang sedang berlangsung, Kaitan dunia nyata, Refleksi.

Perbedaan Pembelajaran Konvensional dengan Berbasis Proyek Project based learning merupakan model pembelajaran yang menggunakan masalah sebagai langkah awal dalam mengumpulkan dan mengintegrasikan pengetahuan baru berdasarkan pengalamannya dalam beraktifitas secara nyata. Project based learning dirancang untuk digunakan pada permasalahan komplek yang diperlukan pelajar dalam melakukan insvestigasi dan memahaminya. Pendekatan dalam mengembangkan pembelajaran berbasis proyek mengacu pada hal-hal sebagai berikut :

a) Kurikulum : Project Based Learning tidak seperti pada pembelajaran tradisional, karena memerlukan suatu strategi sasaran di mana proyek sebagai pusat.

b) Responsibility : Project Based Learning menekankan responsibility dan answerability para siswa ke diri dan panutannya. 
c) Realisme : kegiatan pelajar difokuskan pada pekerjaan yang serupa dengan situasi yang sebenarnya atau sesuai dengan profesi sesungguhnaya. Aktifitas ini mengintegrasikan tugas otentik dan menghasilkan sikap profesional.

d) Active-learning : menumbuhkan isu yang berujung pada pertanyaan dan keinginan siswa untuk menemukan jawaban yang relevan dan fakta, sehingga dengan demikian telah terjadi proses pembelajaran yang mandiri.

e) Umpan Balik : diskusi, presentasi, dan evaluasi terhadap para pelajar menghasilkan umpan balik yang berharga. Ini mendorong kearah pembelajaran berdasarkan pengalaman.

f) Keterampilan Umum : Project Based Learning dikembangkan tidak hanya pada ketrampilan pokok dan pengetahuan saja, tetapi juga mempunyai pengaruh besar pada keterampilan yang mendasar seperti pemecahan masalah, kerja kelompok, berpikir kritis dan self-management bahkan juga dapat berdampak pada sikap atau attitude siswa.

g) Driving Questions : Project Based Learning difokuskan pada pertanyaan atau permasalahan yang memicu pelajar untuk berbuat menyelesaikan permasalahan dengan konsep, prinsip dan ilmu pengetahuan yang sesuai.

h) Constructive Investigations : Project Based Learning sebagai titik pusat, proyek harus disesuaikan dengan kondisi kemampuan pengetahuan para siswa yang melaksanakan Project Based Learning.

i) Autonomy : proyek menjadikan aktifitas pelajar sangat penting.

Pada proses pelaksanaan Project Based Learning, ada fokus yang besar terhadap siswa memahami apa yang mereka lakukan, mengapa hal tersebut penting, dan bagaimana mereka akan dinilai. Prinsip yang mendasari adalah bahwa dengan aktifitas kompleks pada pembelajaran pada umumnya, kebanyakan proses pembelajaran yang terjadi tidak tersusun dengan baik. Alternatif penggunaan Project Based Learning adalah sesuatu yang sangat berbeda. Dari pengalaman terdapat dua dimensi untuk menggolongkan alternatif Project Based Learning atau PBL :

a. Penyelesaian tugas dan pembelajaran pengetahuan yang pokok,

b. Manajemen proyek dan pembelajaran ketrampilan secara umum. Aktifitas para guru dan siswa saling bertukar-tukar tergantung pada derajat tingkat kendali yang diberikan kepada para pelajar dalam kedua dimensi.

\section{B. Merancang Pembelajaran dengan PBL}

Pada pendekatan Project Based Learning, guru berperan sebagai fasilitator bagi siswa untuk memperoleh jawaban dari pertanyaan penuntun. Sedangkan pada kelas "konvensional" guru dianggap sebagai seseorang yang paling menguasai materi dan karenanya semua informasi diberikan secara langsung kepada siswa. Pada kelas Project Based Learning, siswa dibiasakan bekerja secara kolaboratif, penilaian dilakukan secara autentik, dan sumber belajar bisa sangat berkembang. Hal ini berbeda dengan kelas "konvensional" yang terbiasa dengan situasi kelas individual, penilaian lebih dominan pada aspek hasil daripada proses, dan sumber belajar cenderung stagnan. Langkah-langkah pembelajaran dalam Project Based Leraning sebagaimana yang dikembangkan oleh The George Lucas Educational Foundation (2005) terdiri dari :

a. Start With the Essential Question

Pembelajaran dimulai dengan pertanyaan esensial, yaitu pertanyaan yang dapat memberi penugasan siswa dalam melakukan suatu aktivitas. Mengambil topik yang sesuai dengan realitas dunia nyata dan dimulai dengan sebuah investigasi mendalam. Guru berusaha agar topik yang diangkat relefan untuk para siswa (The George Lucas Educational Foundation : 2005).

b. Design a Plan for the Project

Perencanaan dilakukan secara kolaboratif antara guru dan siswa. Dengan demikian siswa diharapkan akan merasa "memiliki" atas proyek tersebut. Perencanaan berisi tentang aturan main, pemilihan aktivitas yang dapat mendukung dalam menjawab pertanyaan esensial, dengan cara mengintegrasikan berbagai subjek yang mungkin, serta mengetahui alat dan bahan yang dapat diakses untuk membantu penyelesaian proyek (The George Lucas Educational Foundation : 2005).

c. Create a Schedule

Guru dan siswa secara kolaboratif menyusun jadwal aktivitas dalam menyelesaikan proyek. Aktivitas pada tahap ini antara lain :

(1) membuat timeline untuk menyelesaikan proyek,

(2) membuat deadline penyelesaian proyak,

(3) membawa siswa agar merencanakan cara yang baru,

(4) membimbing siswa ketika mereka membuat cara yang tidak berhubungan dengan proyek, (5) meminta siswa untuk membuat penjelasan (alasan) tentang pemilihan suatu cara (The George Lucas Educational Foundation : 2005).

d. Monitor the Students and the Progress of the Project

Guru bertanggungjawab untuk melakukan monitor terhadap aktivitas siswa selama menyelesaikan proyek. Monitoring dilakukan dengan cara menfasilitasi siswa pada setiap proses. Dengan kata lain guru berperan menjadi 
mentor bagi aktivitas siswa. Agar mempermudah proses monitoring, dibuat sebuah rubrik yang dapat merekam keseluruhan aktivitas yang penting (The George Lucas Educational Foundation : 2005).

e. Asess the Outcome

Penilaian dilakukan untuk membantu guru dalam mengukur ketercapaian standar, berperan dalam mengevaluasi kemajuan masing-masing siswa, memberi umpan balik tentang tingkat pemahaman yang sudah dicapai siswa, membantu guru dalam menyusun strategi pembelajaran berikutnya (The George Lucas Educational Foundation : 2005).

f. Evaluate the Experience

Pada akhir proses pembelajaran, guru dan siswa melakukan refleksi terhadap aktivitas dan hasil proyek yang sudah dijalankan. Proses refleksi dilakukan baik secara individu maupun kelompok. Pada tahap ini siswa diminta untuk mengungkapkan perasaan dan pengalamanya selama menyelesaikan proyek. Guru dan siswa mengembangkan diskusi dalam rangka memperbaiki kinerja selama proses pembelajaran, sehingga pada akhirnya ditemukan suatu temuan baru (new inquiry) untuk menjawab permasalahan yang diajukan pada tahap pertama pembelajaran (The George Lucas Educational Foundation : 2005).

\section{HASIL DAN PEMBAHASAN}

Beberapa sekolah menengah atas yang ada di Kabupaten Banyumas pernah mengembangkan pembelajaran berbasis proyek. Satu diantaranya yaitu SMA Nasional 3 Bahasa Putera Harapan Purwokerto khususnya pembelajaran untuk siswa kelas XI IPS pada mata pelajaran Geografi .

* Permasalahan yang dikembangkan dalam PBL

Dalam pengembangan pembelajaran, guru sebagai fasilitator menentukan permasalahan yang terjadi di lingkungan sekitar sekolah. Permasalahan yang dimunculkan yaitu terganggunya proses belajar mengajar di kelas yang disebabkan oleh banyak siswa yang susah jauh dari gawainya yang kadang juga mereka gunakan untuk gaming secara online. Berdasarkan permasalahan yang ditemukan itu, guru membuat gambaran singkat mengenai kondisi lingkungan dan rancanan singkat dari pembelajaran yang akan dikembangkan seperti berikut. Di sekolah terdapat banyaknya siswa dari kalangan menengah keatas sehingga hamper semua siswa pasti membawa gawai masing-masing bahkan ada yang membawa 2 perangkat, baik gawai maupun laptop atau notebook. Hal ini tentunya berpengaruh terhadap prestasi dan khususnya keaktifan siswa dalam mengikuti pembelajaran. Sehubungan dengan hal itu, maka siswa kelas XI IPS diberi tugas untuk melakukan pengamatan, diskusi, wawancara tentang pentingnya menyelesaikan sekolah demi masa depan masing-masing dan pengamatan dilakukan wawancara antar sesama rekan untuk dapat mengetahui latar belakang siswa masing-masing sehingga selanjutnya siswa mampu membuat portofolio hasil proyeknya dan mempresentasikan di depan Bapak / Ibu guru serta semua siswa dalam kelas dan mampu memahami akan pentingnya menghargai dan memanfaatkan waktu dengan sebaik mungkin apalagi selama berada disekolah. Perlunya memaksimalkan waktu untuk belajar dan bersosialisasi dengan seluruh warga sekolah (guru dan teman-teman sekolahnya) agar dapat membentuk kakrakter positif yang membudaya..

* Desain Proyek yg dikembangkan

Pada pengembangan rancangan pembelajaran, guru menyusun RPP (Rencana Pelaksanaan Pembelajaran) berbasis proyek. Komponen-komponen dalam RPP yang dikembangkan sesuai dengan standar dalam pengembangan RPP yang berlaku, hanya saja diberikan komponen-komponen tambahan yang menunjang dalam pengembangan pembelajaran berbasis proyek. Adapun rencana pelaksanaan pembelajaran.

\begin{tabular}{|l|l|}
\hline Identitas Sekolah & \\
\hline Sekolah & SMA NASIONAL 3 BAHASA PUTERA HARAPAN \\
\hline Alamat & Jl. S.Parman, depan stadion mini purwokerto \\
\hline Kelas sasaran & XI IPS \\
\hline Siswa & 18 orang \\
\hline
\end{tabular}

Tinjauan Unit

Judul Unit :

Membudayakan Pembelajaran Positif dan

Berkarakter 
Mampu mempresentasikan hasil nya kepada guru, mempublikasikan melalui majalah dinding, menyampaikan antar teman (siswa) dan bisa sharing akan kekurangan dan kelebihan seringannya bermain gaming apalagi game online baik menggunakan hp ataupun perangkat lainnya.

\section{Mata Pelajaran}

Geografi

Kelas

XI IPS

Perkiraan Waktu Yang Dibutuhkan

$4 \mathrm{X}$ pertemuan ( 1 bulan ) : $2 \mathrm{X}$ di kelas, $2 \mathrm{X}$ di luar kelas.

Dasar Unit

Standard dan Tolok Ukur Isi Yang Ditargetkan

1.1 Mengidentifikasi perilaku menyimpang dengan Indikator :

Menerapkan konsep-konsep dasar Sosiologi untuk memahami ragam gejala sosial di masyarakat.Menjelaskan penyebab terjadinya gangguan pada alat pernafasan manusia.

\section{Tujuan Siswa/Hasil Pembelajaran}

- Siswa dapat menjelaskan teori perilaku menyimpang

- Siswa mampu mengklasifikasikan faktor penyebab perilaku menyimpang.

- $\quad$ Siswa mampu mengelompokkan cara-cara pengendalian sosial.

\section{Pertanyaan-pertanyaan Yang Berkaitan Dengan Lingkup Kurikulum}

Pertanyaan

1. Mengapa kita belajar dengan bersungguh-sungguh?

Mendasar

Pertanyaan Unit

1. Apakah hasil yang kita dapat dengan rajin dan tekun belajar?

2. Bagaimana pengaruh gaming untuk psikologis, minat dan kesiapan belajar siswa?

Di sekitar sekolah terdapat banyak siswa yang masih belum dapat membuat management waktu dengan baik, khususnya membagi waktu antara belajar dan bermain hp (gaming). Sehingga hal ini tentunya berpengaruh terhadap hasil belajar, kesiapan dan minat siswa untuk dapat focus dalam pembelajaran baik di sekolah maupun dirumah. Sehubungan dengan hal itu, maka siswa kelas XI IPS diberi tugas untuk melakukan pengamatan, diskusi, wawancara dengan rekan sekelas mereka sehingga nantinya akan mendapatkan informasi yang melatarbelakangi belum tercapainya managemen waktu yang baik untuk siswa tersebut. 


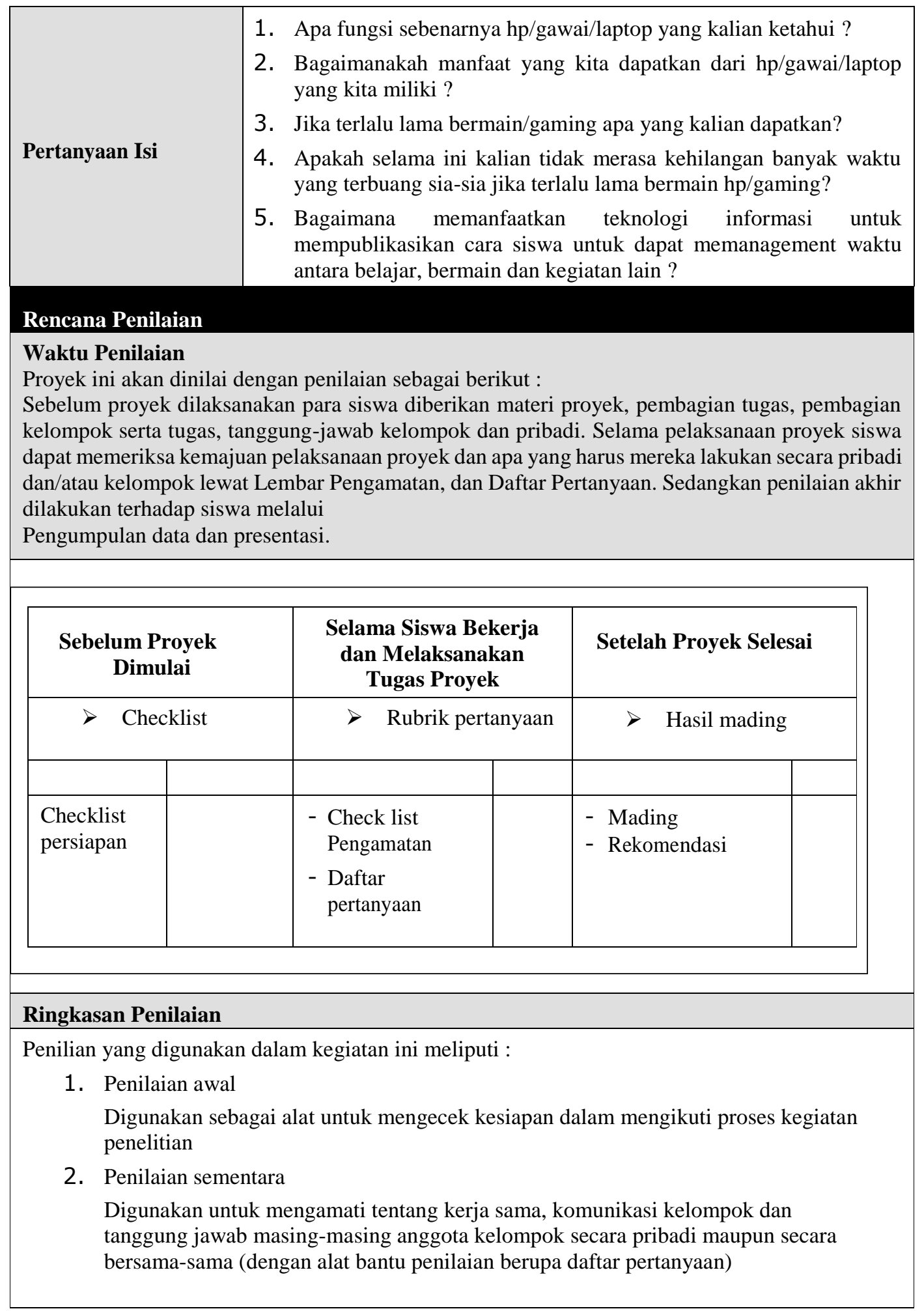

\section{Penilaian akhir}

Digunakan untuk mengetahui sejauh mana siswa mampu menghasilkan produk yang akan disampaikan melalui presentasi.

\section{Rincian unit}

Prasyarat Kecakapan (kemampuan Prasyarat) 
Dalam pembagian kelompok, guru mempertimbangkan kemampuan siswa dalam hal menulis, berkomunikasi, menganalisa data dan menggunakan teknologi.

\section{Prosedur Pengajaran (prosedur instruksi)}

Siswa ditugaskan :

Pertemuan pertama (pagi hari) 2X35 menit

1. Penjelasan proyek, pembagian kelompok dan penyusunan jadwal kegiatan dengan bimbingan guru.

2. Penjelasan materi melalui PPT.

3. Mengidentifikasi hal-hal yang ditimbulkan dengan gaming.

Pertemuan kedua (sore hari) 2X35 menit

1. Melakukan pengamatan ke kke rekan-rekan untuk hal-hal penyebab candunya anak terhadap gaming dengan wawancara dan observasi. Setiap kelompok melakukan penelitian atau pengujian.

2. Membandingkan perbedaan siswa yang tidak candu dalam bermain gaming dan yang candu gaming.

3. Siswa melakukan wawancara/sharing dengan sesama siswa .

4. Siswa melakukan diskusi dari hasil pengamatan dan wawancara.

Pertemuan ketiga (pagi hari) 2X35 menit

1. Siswa mempresentasikan hasil proyeknya di depan bapak/ibu guru serta semua siswa.

2. Siswa dengan bekerjasama dengan waka kesiswaan untuk melakukan webinar tentang bulding time management yang diisi dari Binus.

3. Siswa mempublikasikan hasil penelitian melalui majalah dinding.

Sebagai kegiatan tindak lanjut siswa menerapkan hasil penelitian dalam kehidupan seharihari untuk membiasakan diri untuk dapat "building time management".

\begin{tabular}{|l|l|}
\hline Mengakomodasi Pembelajaran yang Berbeda \\
\hline $\begin{array}{l}\text { Siswa } \\
\text { Berkebutuhan } \\
\text { Khusus }\end{array}$ & $\begin{array}{l}\text { Guru melakukan pendampingan kepada siswa saat pelaksanaan } \\
\text { webinar. }\end{array}$ \\
\hline $\begin{array}{l}\text { Berkoordinasi } \\
\text { dengan pengisi } \\
\text { webinar }\end{array}$ & Guru membantu mengkomunikasikan dengan Binus. \\
\hline
\end{tabular}

\begin{tabular}{|c|c|}
\hline Siswa Berbakat & $\begin{array}{l}\text { Guru memberi kesempatan kepada siswa untuk sharing } \\
\text { masalah dan hal-hal yang dihadapi dengan memanagement } \\
\text { waktunya. }\end{array}$ \\
\hline \multicolumn{2}{|c|}{ Alat dan Bahan yang dibutuhkan : } \\
\hline \multicolumn{2}{|l|}{ Teknologi-Perangkat Keras } \\
\hline $\begin{array}{l}\square \text { Camera } \\
\square \text { Computer(s) } \\
\square \text { Digital Camera } \\
\square \text { DVD Player } \\
\square \text { Internet Connection }\end{array}$ & $\begin{array}{ll}\square \text { Laser Disk } & \square \text { VCR } \\
\square \text { Printer } & \square \text { Video Camera } \\
\square \text { Projection System } & \square \text { Video Conferencing Equip. } \\
\square \text { Scanner } & \square \text { Other } \\
\square \text { Television } & \end{array}$ \\
\hline \multicolumn{2}{|c|}{ Technology - Software (Click boxes of all software needed.) } \\
\hline \multicolumn{2}{|c|}{\begin{tabular}{|ll}
$\square$ Database/Spreadsheet & $\square$ Image Processing \\
$\square$ Desktop Publishing & $\square$ Internet Web Browser \\
$\square$ E-mail Software & $\square$ Multimedia \\
$\square$ Encyclopedia on CD-ROM & \\
\end{tabular}} \\
\hline Materi & Building Time Management. \\
\hline Alat & Media untuk zoom meeting dalam webinar dengan Binus. \\
\hline Sumberdaya Internet & Wifi/Kuota \\
\hline
\end{tabular}




\begin{tabular}{|l|l|}
\hline Sumberdaya Lainnya & Lingkungan sekolah/rumah yang mendukung. \\
\hline Tabel 2. Rencana Pelaksanaan Pembelajaran (RPP) Berbasis Proyek Beberapa komponen-komponen \\
tambahan yang tercantum dalam RPP di atas seperti Judul Proyek, Ringkasan Unit, Pertanyaan \\
Kerangka Kurikulum, Kebutuhan siswa berkebutuhan khusus, Mengakomodir siswa berbakat.
\end{tabular}

Pelaksanaan PBL di SMA Nasional 3 Bahasa Putera Harapan Purwokerto.

Pelaksanaan pembelajaran berbasis proyek di SMA Nasional 3 Bahasa Putera Harapan Purwokerto ini berjalan sesuai dengan rencana yang tertuang dalam RPP berbasis proyek.

Dalam pelaksanaan pembelajaran berbasis proyek diawali dengan melakukan sosialisasi terhadap stakeholder yang terlibat dalam proyek pembelajaran tersebut seperti peran semua siswa, orang tua siswa, guru-guru untuk memberikan masukan, para Waka (Kurikulum, Kesiswaan, Sarpras), peran serta dari Binus sebagai narasumber,. Kegiatan sosialisasi tersebut bertujuan menyampaikan informasi kepada semua siswa yang terlibat terkait dengan pelaksanaan pembelajaran berbasis proyek yang akan dilaksanakan, sehingga harapannya semua siswa akan dapat merubah diri dan dapat menciptakan building time management untuk waktu ke depan.

Selain melakukan sosialisasi terhadap stakeholder yang akan terlibat dalam pembelajaran berbasis proyek, guru juga melakukan sosialisasi mengenai rencana pelaksanaan pembelajaran berbasis proyek terhadap siswa yang akan melaksanakannya. Hal ini bertujuan untuk memunculkan pemahaman siswa dan meningkatkan antusias dan motivasi siswa dalam melaksanakan pembelajaran berbasis proyek.

Dalam melakukan sosialisasi rencanan pelaksanaan penbelajaran berbasis proyek, guru menjelaskan mulai dari topik permasalahan, tujuan pembelajaran, kompetensi dasar yang ingin dicapai, metode dan langkah-langkah pembelajaran yang akan dilaksanakan dalam memecahkan permasalah serta hingga penilaian terhadap proses dan hasil dari pembelajaran.

Berdasarkan rencana pelaksanaan pembelajaran berbasis proyek yang sudah dikembangkan, pembelajaran dilakukan menjadi 4 kali pertemuan dengan rincian 2 kali pertemuan di dalam kelas dan 2 kali pertemuan di luar kelas. Seperti halnya pembelajaran pada umumnya, pembelajaran diawali dengan pendahuluan dengan melakukan appersepsi. Guru menyampaikan tujuan dan kompetensi dasar yang ingin dicapai pada pembelajaran berbasis proyek itu, kemudian memberikan pertanyaan-pertanyaan terkait materi yang akan dibahas dalam pembelajaran melalui pertanyaan kerangka kurikulum yang sudah dikembangkan sebelumnya yang terdiri dari pertanyaan mendasar (essensial), pertanyaan unit dan pertanyaan isi (konten). Pertanyaan yang disampaikan pada sesi pendahuluan yaitu pertanyaan mendasar dan unit, sedangkan pertanyaan isi atau konten digunakan untuk melakukan evaluasi pembelajaran.

\begin{tabular}{|c|c|}
\hline \multicolumn{2}{|c|}{ Pertanyaan-pertanyaan Yang Berkaitan Dengan Lingkup Kurikulum } \\
\hline $\begin{array}{l}\text { Pertanyaan } \\
\text { Mendasar }\end{array}$ & 1. Mengapa kita harus bisa menciptakan bulding time management? \\
\hline Pertanyaan Unit & $\begin{array}{l}\text { 2. Bagaimana pemanfaatan hp/gawai/laptop yang sesungguhnya? } \\
\text { 3. Bagaimana pengaruhnya bagi siswa yang candu gaming? }\end{array}$ \\
\hline Pertanyaan Isi & $\begin{array}{l}\text { 4. Apakah ada pengaruhnya untuk psikologis, minat dan } \\
\text { kesiapan belajar siswa dengan seringnya gaming? } \\
\text { 5. Apakah dampak yang ada pada siswa dengan seringnya gaming? } \\
\text { 6. Apakah perlu adanya building time management agar } \\
\text { siswa dpt mengatur waktu dengan baik? } \\
\text { 7. Apakah yang bis akita lakukan untuk dapat membudayakan } \\
\text { building time management? } \\
\text { 8. Bagaimana membuat siswa menyadari pentingnya teknologi } \\
\text { informasi untuk kemajuan belajar dan tidak disalah gunakan hanya } \\
\text { untuk gaming? }\end{array}$ \\
\hline
\end{tabular}

Tabel 3. Pertanyaan Kerangka Kurikulum

Pada pelaksanaan pembelajaran berbasis proyek, langkah-langkah pembelajaran yang dilaksanakan seperti dalam rencana pelaksanaan pembelajaran (RPP) yang terdiri dari 4 pertemuan. Prosedur Pengajaran atau Prosedur Instruksi seperti pada tabel berikut. 


\section{Prosedur Pengajaran (prosedur instruksi)}

Siswa ditugaskan :

Pertemuan pertama (pagi hari) 2 X35 menit

1. Penjelasan proyek, pembagian kelompok dan penyusunan jadwal kegiatan dengan bimbingan guru.

2. Melalui bimbingan guru akan komunikasi dengan penyiapkan data untuk pertanyaan.

3. Mengidentifikasi hal-hal akan diteliti.

Pertemuan kedua (sore hari) 2X35 menit

1. Melakukan pengamatan dan sharing dengan rekan sesama siswa tentang kasus yang akan diteliti. Setiap kelompok melakukan penelitian atau pengujian.

2. Menyiapkan data yang akan diberikan ke siswa.

3. Siswa melakukan komunikasi dengan guru pendamping dan waka yang teerlibat (waka kurikulum, kesiswaan dan sarpras).

4. Guru membantu mengkomunikasikan dengan Binus sebagai pengisi dalam building time management.

5. Siswa melakukan diskusi dari hasil pengamatan dan wawancara.

Pertemuan ketiga (pagi hari) 2X35 menit

1. Team dari Binus sebagai narasumber didampingi guru walikelas dan waka untuk menggerakkan siswa dalam mengikuti webinar building time management.

2. Siswa melakkukan evaluasi kegitan webinar.

3. Siswa mempublikasikan hasil penelitian melalui majalah dinding.

Sebagai kegiatan tindak lanjut siswa menerapkan hasil penelitian dalam kehidupan seharihari untuk membiasakan diri melakukan building time managemen.

Tabel 4. Prosedur Pengajaran atau Prosedur Instruksi

Pada proses pembelajarannya, siswa melakukan aktivitas-aktivitas sesuai dengan langkah-langkah pembelajaran yang dikembangkan dalam RPP yang meliputi kegiatan pengamatan (observasi) terhadap obyek-obyek pembelajaran dalam hal ini adalah lingkungan sekolah dengan banyaknya siswa yang tidak dapat membagi waktu dengan baik karena gaming. Kegiatan pengamatan atau observasi yang dilaksanakan oleh siswa SMA Nasional 3 Bahasa Putera Harapan Purwokerto seperti ada pada gambar.

Pendidikan di Sekolah Nasional 3 Bahasa Putera Harapan mencakup banyak hal. Tidak hanya dari segi akademik, namun juga segi pendidikan bahasa, pendidikan karakter, pendidikan keagamaan serta program pengembangan diri. Untuk mendukung hal-hal di atas, Sekolah Putera Harapan memberikan beragam kegiatan yang penuh makna. Salah satu contohnya adalah kegiatan Seminar dengan tema "Building Time Management" yang merupakan hasil kolaborasi antara Sekolah Putera Harapan dengan BINUS Creates untuk mendukung program pengembangan diri bagi peserta didik. Kegiatan webinar dilaksanakan pada hari Kamis, 10 Desember 2020, dengan pembicara Ahmad Syauqi Jalaluddin, S.Kom, M.M. seorang Technopreneur Curriculum Developer dan profesi lainnya, dengan diikuti oleh seluruh peserta didik SMA Putera Harapan.

Dalam pembahasannya materi pembicara menyampaikan bahwa untuk menentukan suatu prioritas ada 4 kuadran sebagai tolak ukur yang digunakan diantaranya :

1. Penting dan mendesak

2. Penting tidak mendesak

3. Tidak penting tapi mendesak

4. Tidak penting, tidak mendesak

Kemudian juga diberikan trips dan trik untuk terhindar dari rasa malas. Trik itu seperti :

1. Jangan menunda

Jika anda sudah terbiasa mengerjakan suatu hal secara langsung atau dalam kata lain tidak menundanya niscaya anda dapat terhindar dari rasa malas.

2. Buat target

Tanamkan pada diri anda bahwa anda pasti dapat menyelesaikan target yang anda buat. Dengan demikian anda akan merasa lebih bersemangat dan giat dalam melakukan suatu hal.

3. Olahraga dan pola hidup sehat 
Malas juga di sebabkan kurangnya nutrisi dalam tubuh. Jika nutrisi kurang pasti anda akan merasa bahwa tubuh anda lemas dan akan malas melakukan apapun. Cara mengatasi hal tersebut adalah dengan cara berolah raga dan pola hidup sehat. Dengan demikian tubuh anda akan selalu terasa segar dan bersemangat dalam melakukan suatu hal ataupun pekerjaan.

4. Buatlah daftar

Dengan pembuatan daftar anda pasti akan berusaha melakukan sesuatu dengan baik dan cepat agar semua daftar yang anda buat dapat di terlaksana semuanya.

5. Hadiahi diri sendiri

Jika semua target dan juga daftar anda dapat terpenuhi jangan ragu untuk memberikan hadiah pada diri anda sendiri. Karena dengan menghadiahi diri anda sendiri maka secara psikologis dapat membuat diri anda melawan rasa malas yang ada dalam tubuh anda.

6. Memotivasi diri sendiri

Usahakan untuk memotivasi diri anda sendiri, tanamkan pada diri and bahwa anda bukanlah orang yang malas dan malas itu akan merusak banyak hal yang ada pada diri anda.

7. Hindari tempat tidur ataupun sofa

Jika belum waktunya istirahat jangan sampai anda mendekati tempat tidur ataupun sofa karena biasanya tubuh akan tersugesti bermalas-malasan.

8. Hindari hal menyenangkan di pagi hari

Jika melakukan kegiatan berat di siang hari, maka keadaan tubuh anda sudah tidak akan mampu melakukan kegiatan berat di siang hari dengan maksimal.

9. Buat jadwal harian

Berusaha melakukan jadwal yang sudah anda buat tersebut secara tuntas.

10. Pola hidup teratur

Pastikan segala sesuatu yang ada di hidup anda sudah anda atur dengan baik.

Kegiatan program pengembangan diri yang kali ini karena situasi pandemi dilaksanakan secara online dengan metode webinar ini sangat bermanfaat bagi Peserta Didik. Sekolah berharap, dengan pengaturan waktu yang tepat maka Peserta Didik akan menjadi pribadi yang lebih baik.

\section{Kegiatan Guru dalam Pembelajaran Berbasis Proyek.}

Pembelajaran berbasis proyek didesain sebagai suatu pembelajaran dengan komponen meliputi proses, sasaran hasil, isi, sumber daya, penilaian, dan lain-lain. Dalam Project Based Learning, instruksi terjadi melalui pelatihan, diskusi, bimbingan, dan lain-lain. Bagian ini sebagai aktivitas guru dalam pendekatan Project Based Learning.

a. Perancangan atau Desain Proyek.

Tahap perancangan atau desain proyek adalah sangat pokok. Perancangan yang salah dari aktivitas proyek akan menyebabkan dampak yang tidak baik pada proses belajar mengajar. Guru menggambarkan isi, mengatur pertanyaan, hasil pembelajaran, material pendukungan, dan strategi penilaian. Aktivitas ini diselenggarakan oleh suatu tim guru dengan disiplin ilmu yang sesuai. Isi atau content dalam pembelajaran berbasis proyek ditentukan oleh guru dengan memutuskan topik apa yang tercakup pada proyek yang disesuaikan dengan kompetensi dasar yang ingin dicapai. Proyek yang baik adalah yang cocok untuk lintas disiplin atau lintas mata pelajaran atau bidang studi. Pengembangan pembelajaran berbasis proyek pada umumnya dibuat berdasarkan kurikulum baku dan sebagai konsekuensinya, desain memerlukan unsur-unsur dalam kurikulum yang ada dan mengkombinasikan unsur-unsur instruksi dari berbagai disiplin ilmu. Hasil pembelajaran (learning outcomes) yang menjadi sasaran dan objektifitas pengukuran hasil pembelajaran sangat diperlukan. Para guru harus menandai pengetahuan pokok dan ketrampilan yang akan diperoleh pelajar serta menguraikan keterampilan umum yang ditargetkan oleh proyek. Sasaran hasil pembelajaran harus dipetakan ke aktivitas proyek. Fokus dalam perancangan pembelajaran berbasis proyek untuk memotivasi pelajar dan memperoleh keterlibatannya secara penuh, proyek harus dibuat menantang dan berhubungan dengan permasalahan hidup nyata. Guru harus menentukan dan mengatur pertanyaan yang akan dihadapi pelajar dan mendorong pelajar untuk menyelesaikan permasalahan. Aktifitas dalam pembelajaran berbasis proyek harus melibatkan para pelajar di dalam aktifitas yang realistis. Tahap desain menentukan aktifitas seperti penyelidikan, riset, pemecahan masalah, penggunaan alat bantu, dan lain-lain. Metoda yang dirancang guru juga menentukan cara untuk menerapkan proyek organisasi kelas dan kelompok, pelatihan, dan material pendukung, serta prosedur umpan balik, sumber daya, dan lain-lain. Penilaian yang dilakukan dalam pembelajaran berbasis proyek merupakan strategi untuk mengevaluasi hasil yang dicapai pelajar harus ditentukan. Penilaian sendiri dan oleh tim ahli mempunyai suatu peran penting dalam pendekatan PBL.

b. Monitoring dan pengendalian.

Setelah menyelesaikan perencanaan proyek dan sebelum menjalankan kegiatan pelajar, guru harus mengorganisir kelas, membentuk kelompok, mengorganisir material, menugaskan pekerjaan, mengorganisir 
pelatihan, dan jadwal aktivitas . Setelah proyek diberikan dan ketika pelajar melaksanakan tugas proyek, guru harus memonitor kemajuan, mengkoordinir aktivitas, dan menyediakan sumber daya yang diperlukan. Pelajar harus mengakses dokumen dan melayani pelajar secara individu dan kelompok. Pelajar juga harus memonitor kerja kelompok dan bila terjadi konflik inter-personal, segera menyelesaikannya.

c. Support di dalam model PBL, instruksi yang terjadi kebanyakan secara tidak langsung.

Guru dapat memulai dengan instruksi langsung terbatas pada hal-hal yang dasar. Guru menyiapkan dan menyediakan selebaran tugas, seperti selebaran penjelasan metodologi, petunjuk, atau petunjuk penggunaan. Juga menyediakan akses kepada material pelajaran dan sumber yang lain, seperti catatan ceramah kuliah, pembicaraan video-tape dan proses; melakukan latihan di tempat kerja dan membuat demonstrasi jika dibutuhkan. Selain daripada itu mengorganisir pembicaraan dan seminar sekitar isu kompleks dengan mengundang tenaga ahli atau para professional. Instruksi juga terjadi melalui pelatihan. Pelajar senior dapat membimbing ke tingkat yang lebih rendah, serta dapat membantu mengorganisir pekerjaan, keputusan struktur, memecahkan permasalahan dan pengoperasian perangkat.

d. Penilaian.

Penilaian harus disatukan ke dalam aktifitas proyek. Karena PBL dititik beratkan pada keberhasilan pelajar, evaluasi diri dan oleh tim ahli harus dimasukkan ke dalam strategi penilaian.

e. Umpan balik.

Pengalaman dari implementasi PBL menjadi sesuatu yang berharga, yang memberikan kesempatan untuk melakukan peningkatan kemampuan. Pelajar dan guru dapat menyediakan umpan balik mengenai perencanaan, organisasi, support, dan penilaian proyek. Umpan balik adalah sesuatu yang pokok dalam PBL. Umpan balik dapat dimulai dari para guru, pelatih, ahli, klien, dan lain-lain. Presentasi dan diskusi adalah sarana yang baik untuk menjadi umpan balik. Para guru harus mengorganisir prosedur umpan balik.

Kegiatan siswa dalam Pembelajaran Berbasis Proyek

a. Pengamatan atau observasi

b. Penelitian atau riset

c. Eksplorasi dan eksploitasi

d. Kolaborasi, diskusi

e. Berpikir tingkat tinggi

f. Pembuatan produk pembelajaran

g. Presentasi atau publikasi hasil pembelajaran

\section{KESIMPULAN}

Dengan menerapkan pembelajaran berbasis proyek, siswa dituntut aktif dalam proses pembelajaran. Siswa akan merasakan langsung dalam mengembangkan pembelajaran, mendapatkan pengetahuan. Hal ini dikarenakan siswa terlibat langsung dalam pencarian informasi atau materi pembelajaran melalui langkah- langkah kegiatan yang kontekstual. Siswa diajak melakukan pengamatan atau observasi, penelitian, diskusi kelas, serta melakukan presentasi atas hasil pemikiran atau penemuannya. Siswa juga diajak berpikir tingkat tinggi dengan melakukan pemecahan terhadap suatu masalah yang dibahas pada pembelajaran berbasis proyek. Dengan penerapan pembelajaran berbasis proyek, kemampuan siswa terkait kemampuan keterampilan abad 21 akan tercapai. Pada pelaksanaan pembelajaran berbasis proyek yang dilaksanakan pada pelajaran geografi kelas XI IPS SMA Nasional 3 Bahasa Putera Harapan Purwokerto masih terdapat beberapa hal yang masih perlu ditingkatkan agar pelaksanaan pembelajaran benar-benar sesuai dengan konsep pembelajaran berbasis proyek. Dalam penyusunan kelompok kerja siswa, guru harus memetakan kompetensi- kompetensi siswa terlebih dahulu, agar dalam proses pembelajaran tidak terjadi kesenjangan proses dan hasil antara kelompok kerja siswa satu dengan yang lain. Selain itu, peran siswa dan guru berkoordinasi. Dengan dibantu guru mengkoordinasikan dengan pihak Binus dalam proyek pembelajaran yang dijelaskan dalam webinar.

\section{DAFTAR PUSTAKA}

[1] Alim Bahri (2009). Sistem Pembelajaran Abad 21 dengan Project Based Learning (PBL). Diambil pada tanggal 5 Januari 2009 dari http://www.ubb.ac.id/menulengkap.php?judul=Sistem\%20 Pembelajaran\%20Abad\%2021\%20dengan\%20\%3CQ\%3EProject\%20Based\%20Learning\%20(PBL)\%3C/ Q\%3E\&\&nomorurut_artikel=252

[2] Anonim (2010), Laporan Pelaksanaan Implementasi Essential Course (EC) tahun 2010, LPMP D.I.Yogyakarta.

[3] Neumont University.(2006).Project Based Learning. Diambil pada tanggal 10 Juli 2007 dari http://www.neumont.edu/future-students/bachelor-project-basedlearning.html

[4] Teach, Intel (2007), "Modul Pelatihan Intel Teach - Getting Started", Intel Education 
[5] Teach, Intel (2008), "Modul Pelatihan Intel Teach - Essentials Course", Intel Education

[6] The George Lucas Educational Foundation .(2005).Instructional Module Project Based Learning. Diambil pada tanggal 10 Juli 2007 dari http://www.edutopia.org/modules/PBL/whatpbl.php 